Annals of Warsaw University of Life Sciences - SGGW

Land Reclamation No 46 (2), 2014: 93-100

(Ann. Warsaw Univ. of Life Sci. - SGGW, Land Reclam. 46 (2), 2014)

\title{
Monitoring of pavement state as a basis for economic regulation of greenhouse gases emissions
}

\author{
MARIA RADKEVICH ${ }^{1}$, ABDULKHAKIM SALOKHIDDINOV ${ }^{2}$ \\ ${ }^{1}$ Tashkent Automobile and Road Construction Institute \\ ${ }^{2}$ Tashkent Irrigation and Melioration Institute
}

\begin{abstract}
Monitoring of pavement state as a basis for economic regulation of greenhouse gases emissions. Road complex which includes a road network with traffic, road services, car repair businesses, and enterprises for the production of fuels and materials for the repair of roads, is an important source of environmental pollution, and the degree of contamination depends on the quality of the road pavement. The present research is aimed to find the interaction between the amount of emissions into the environment from whole road complex and condition of road cover, on creation of a simplified method of determining economic damage from environmental pollution at the road operation and to develop basic mechanism of the economic impact on road services at excess emissions. According to the results of computer experiments mathematical relations of complex road emissions from the evenness of road pavement were obtained. Worked out method of greenhouse (and other) emission inventory permits to determine the total amount of emissions and to identify excess emissions relative to some acceptable level. Definition of economic damage of environmental pollution during road operation can be the basis for determining the amount of ban impositions on road service.
\end{abstract}

Key words: greenhouse gases, economic damage, "road-car" system, pavement evenness, excess of emissions

\section{INTRODUCTION}

Emissions of greenhouse gases and other pollutants in the air cause concern all over the world. A special attention by a world scientific community is paid to the inventory of greenhouse gases.

The reporting on emissions of greenhouse gases becomes obligatory for many international organizations. The international community is also beginning to demand a data on greenhouse gas emissions from various organizations, to beforehand estimate potential economic and financial risks associated with greenhouse gas emissions. Actually a reporting on greenhouse gas emissions becomes as important as environmental impact assessment and control on emissions of conventional pollutants.

Greenhouse gases are not polluting substances in the usual sense of this term. As they do not have a direct deleterious effect on human health or ecosystems, the control is conducted not only on concentration of this or that greenhouse gas near the enterprise, but on absolute value of long-term-emission 
- usually for one year. It does not matter if it was: volley emissions or gradual ones. Emissions during the year, in fact, may greatly influence global greenhouse effect. Neither global nor regional effects are independent from the point of emission. Therefore it is difficult to identify the source of these emissions.

\section{Formulation of the problem}

The present research is aimed to find the interaction between the amount of emissions into the environment from road complex and condition of road cover, on creation of a simplified method of determining economic damage from environmental pollution at the road operation and to develop the basic mechanism of economic impact on road services at excess emissions.

\section{Hypothesis}

Economic damage from environmental pollution at road operation maintenance directly depends on road cover conditions (evenness). Emissions should be determined by the processes accompanying road life cycle: operation, maintenance and repair of roads, traffic, and the car repair.

Then knowing road evenness and the intensity of traffic it is possible quickly to make inventory of emissions and to determine economic damage from environmental pollution by greenhouse gases from all road complex on a whole.

\section{Research goal}

Now there is no single procedures of determining the damage, caused to an environment by road complex, though there are general procedures to assess economic damage from pollution of an environment. Works, directed on the development of a single method of damage assessment caused by greenhouse gases, are conducted by many researchers. At present, in some countries taxes on greenhouse gas $\mathrm{CO}_{2}$ are introduced. Environmental taxes in one form or other exist in all developed countries. In Uzbekistan, the regulation of fines for negative impact on the environment is determined by the Decree of the Cabinet of Counsel on 01.05.2003 N199 "On improving of payment system at environmental pollution and waste disposal in the Republic of Uzbekistan" and the Regulation "On the order of application of compensatory payments at environmental pollution and waste disposal in the Republic of Uzbekistan" on 01.05.2003. However, these documents are not considered at the determination of compensatory payments. According to the State Committee of Nature Protection, environmental impact assessment is conducted only for fleet.

Our goal is to create a method for inventory of greenhouse gas emissions from the road complex of the republic on the basis of which we can estimate the excess emissions relative to some level, which would determine the amount of additional damage to the environment. At this approach developing of taxes and penalties system is possible. For reasonable tax it is necessary to formulate first of all a clear definition of all sources of greenhouse gas emissions and the definition of damage.

Tracing the relationship between the quality of the road cover and economic damage from pollution will increase the responsibility of enterprises of State JSC Automobile roads of Uzbekistan (Uzav- 
toyul). High quality of road maintenance can be achieved through the introduction of the system of taxes and penalties as a way of financing neccesary repairs and conservation works. Assessment of the damage, caused by road system as a whole, permits to specify the size of compensatory payments, that will be of great value for the budget of the Republic, as $50 \%$ of compensatory payments are directed to Republican budget.

Regular monitoring of environmental damage from road complex can be achieved by creating a monitoring system for road evenness and determination of economic damage caused. It should also be noted that although the researches were carried out for conditions of Uzbekistan, the developed method for environmental damage assessment from road complex can be used in any other region, where there are difficulties associated with the financing of road maintenance.

\section{MATERIALS AND METHODS}

Many researchers are involved in evaluation of economic damage, caused by environmental pollution. Since the present research is aimed on identifying emission inventory method, we will analyzed the existing methods of GHG inventory (and other) emissions (Berdin et al. 2004, Methods of determining the emissions of harmful substances... 2005, IPCC Guidelines... 2006).

All methods existing today can be divided into three types: the fuel consumption of vehicle; the total mileage of vehicle; the fuel quantity sold. These methods have a number of shortcomings - they require data about the fuel consumption of different types of vehicle or statistics on the mileage. It is very difficult to take into account the transit vehicles. Fuel sold can be used not only for vehicles.

There are a number of papers devoted to the development of taxes system on greenhouse gas emissions, but they are not associated with a road complex (Golub et al. 1995, Rochas 2006, Inogamov 2007).

In order to assess the effects in terms of pollutant quantities, changes in vehicle ages and vehicle technology, the emissions model proposed by Hammerstrom (1995) is used in HDM-4. Originally a variety of units were used. The relationships and model coefficients have been adjusted so that all emissions predictions are in terms of grams per vehicle per 1 kilometer (Bennett 1996). The model predicts different components of vehicle exhaust emissions as a function of fuel consumption and speed. Fuel consumption is a function of vehicle speed, which, in turn, depends on road characteristics and the characteristics of the vehicle itself.

The following seven different components of exhaust emissions are considered: hydrocarbon (HC), carbon monoxide (CO), nitrous oxide $\left(\mathrm{NO}_{\mathrm{x}}\right)$, sulphur dioxide $\left(\mathrm{SO}_{2}\right)$, carbon dioxide $\left(\mathrm{CO}_{2}\right)$, particulates (Par), lead $(\mathrm{Pb})$. The greenhouse gas carbon dioxide is determined as follows:

$$
E_{\mathrm{CO}_{2}}=\frac{3.6 \cdot K_{\mathrm{eco} 0} \cdot a_{0} \cdot I F C \cdot 10^{3}}{S P E E D}
$$

where:

$\begin{aligned} E_{\mathrm{CO}_{2}}- & \text { carbon dioxide emissions } \\ & {[\mathrm{g} /(\text { vehicle } \cdot \mathrm{km})], } \\ a_{0}- & \text { model parameter, } \\ K_{\mathrm{eco} 0}- & \text { calibration factor (default } \\ & \text { equals } 1.0), \\ I F C \quad- & \text { instantaneous fuel consump- } \\ & \text { tion }(\mathrm{ml} / \mathrm{s}), \\ S P E E D- & \text { vehicle speed }(\mathrm{km} / \mathrm{h}) .\end{aligned}$


In the proposed methodology of HDM-4, the greenhouse emissions are dependent on speed, which, in turn, are dependent on road quality (roughness) and traffic interactions. Watanatada and Dhareshwar (1986) and Watanatada et al. (1987) have developed a mechanistic approach for determination of vehicle speed using extensive field data collected in Brazil. The model is based on the concept that each vehicle has a set of limiting speeds for open excellent roads $\left(V_{\text {DESIR }}\right)$, curves ( $\left.V_{\text {CURVE }}\right)$, upgrades ( $\left.V_{\text {DRIVE }}\right)$, downgrades $\left(V_{\text {BRAKE }}\right)$ and rough surfaces $\left(V_{\text {ROUGH }}\right)$.

In the Brazilian study, Watanatada et al. (1987) have developed the following equation for predicting roughness constrained speed for asphalt concrete surface:

$V_{\mathrm{ROUGH}}=\frac{A R V_{\mathrm{MAX}}}{a \cdot I R I}$

where:

$V_{\text {ROUGH }}$ - roughness constrained speed $(\mathrm{m} / \mathrm{s})$,

$A R V_{\mathrm{MAX}}$ - maximum rectified velocity $(\mathrm{mm} / \mathrm{s})$,

a $\quad-$ model parameter,

IRI - international roughness index $(\mathrm{m} / \mathrm{km})$.

The impacts of traffic interaction on speed were taken by using three-zone speed flow model (Hoban 1987).

Bennett (1994, 1996), Hammerstrom (1995), Watanatada and Dhareshwar (1986), Watanatada et al. (1987) and Hoban (1987) have presented emissions depending on the vehicle speed, limited smoothness. These models predict only single vehicle emissions, while emis- sions should take into account the flow of cars.

Moreover, none of these studies paid any attention to emissions of the road-car system as a whole (i.e. emissions from the flow of cars, from road repair machines, from auto repair businesses, emissions from fuel and materials for the repair of roads and vehicles). Therefore, the scope of this study includes the establishment of the relationship between emissions of all processes of the road-car complex and evenness of the pavement cover.

Statement of such relationship and assessment of damage caused by emissions will allow to apply economic sanctions for excess emissions to businesses in the road-car complex. For conducting researches, authors used data from the Automobile roads of Uzbekistan (Uzavtoyul) State JSC on conditions of the road cover in the Republic of Uzbekistan, as well as data on the methods of roads repair. These data of the Uzavtoyol include the length of roads in Uzbekistan, including the different types of road cover, and traffic intensity on the roads of different types and categories.

As a basis for greenhouse gas inventory the use of monitoring data of road evenness is proposed. The legal basis of emissions monitoring should provide an assessment system of road cover used in this state. If evenness of road cover is satisfactory, then the greenhouse gas emissions should be recognized as satisfactory, i.e. valid. If evenness is evaluated as bad, it can be assumed that the greenhouse gases emission is higher than the limit.

Researches have been conducted on the possibilities of emission inventory in the road-car system during road operation. 
Computer experiment on the inventory of all emissions in the road-car system for roads with different traffic intensity and the allowable evenness covering, the different composition of traffic and different types of repairs was carried out to obtain a full picture of the process of determining of possible greenhouse (and other) emissions.

To perform a computer experiment, authors used well-known models describing the change speed of the car depending on the evenness of coverage, a change in the road surface roughness over time, taking into account repairs. The experiment was conducted in the following order: (i) Selected process models and data to calculate emissions; (ii) With the help of the selected data models and computer experiment was conducted, representing a variational problem, which includes traffic from 1,000 to 10,000 vehicles per day at permissible flatness of 4 to 14 IRI (according to the norms of Republic of Uzbekistan).

For emissions inventory of the road-car system, emissions on the road at repair works on restore road cover and the production of repair materials were taken into account on the one side. On the other side emissions at driving vehicle, production of maintenance and repair of vehicle, the production of fuel for traffic, as well as materials for the repair of the vehicle were taken into account.

All these values are interrelated and present an evidence of dependence of condition of road cover on its evenness, in particular.

Therefore, to create a regulatory base for monitoring and emission inventory it is necessary to study appropriateness of these relationships and on the basis of these studies to choose criteria for registration and control of emissions. The solution of this problem is sought in the following way: (i) Study of options of road conditions during the road life cycle at different traffic and different schemes of repair; (ii) Study of the change of traffic depending on evenness of road cover: number of trip cycles, changes in amount of emission, depending on speed, frequency of maintenance and repair of vehicle depending on evenness of the road cover and speed; (iii) Data on the amount of emissions from traffic, repair of roads and vehicle, at the production of fuels and materials makes it possible to develop an inventory of emissions.

Data on the amount of emissions from these processes accepted in the work results from cooperation with different scientific-research institutes and laboratories on modern level of technology in automobile industry, maintenance and car repair and road-repair work technology.

\section{RESULTS AND DISCUSSION}

Based on results of computer experiments there were obtained mathematical relations of complex road emissions to the evenness of the road pavement. These relations have the general form:

$$
M=A-N^{2}+B \cdot N+C
$$

where:

$$
\begin{aligned}
M- & \text { mass pollution emissions } \\
& {[\mathrm{t} /(\text { year } \cdot \mathrm{km})], } \\
N \quad- & \text { traffic }(1,000 \text { vehicles/day }) \\
A, B, C- & \text { coefficients depending on the } \\
& \text { evenness of the road cover. }
\end{aligned}
$$


TABLE 1. The coefficients of equation (1) for the greenhouse gas $\mathrm{CO}_{2}$

\begin{tabular}{|l|c|r|r|r|r|r|r|r|r|}
\hline $\begin{array}{l}\text { Evenness } \\
\text { of } I R I \\
(\mathrm{~m} / \mathrm{km})\end{array}$ & 4 & 5 & 6 & 7 & 8 & 10 & 10.5 & 13 & 14 \\
\hline$A$ & 0.4641 & 0.5027 & 0.5297 & 0.6889 & 0.8185 & 0.4585 & 0.2176 & -0.0287 & 0.12 \\
\hline$B$ & 49.396 & 51.5873 & 53.4463 & 54.0504 & 54.7562 & 62.8997 & 67.4689 & 77.467 & 76.695 \\
\hline$C$ & 16.1549 & 9.2579 & 6.6314 & 4.553 & 3.828 & -12.8252 & -27.7053 & -60.6384 & -58.445 \\
\hline
\end{tabular}

The coefficients $A, B, C$ are not constant over time. They depend from the current level of automobile-road complex and should be reviewed periodically.

Coefficients in equation (3) are defined for each pollutant and for different types of road covering. For example, determination of $\mathrm{CO}_{2}$ emissions for covering of capital types: A, B and C, is shown in the Table 1.

As mentioned earlier, the resulting equation determines the excess of actual emissions over specific (satisfactory) one.

To confirm the data field experiments were conducted to establish the dependence of the emission on the evenness of the pavement.

Statistical analysis was carried out in the form of two-factor analysis of variance on two factors: evenness $(6,8,10$ and $13 I R I)$ and traffic $(4,8,12,16$ and 20 thousands of vehicle/day).

As a reiteration, results of computer and physical experiments were accepted. Analysis of variance confirmed statistical significance of selected value, depending on the flatness of the coating emissions and traffic. The degree of influence of flatness is $46.6 \%$, the influence of intensity $-50.1 \%$. The degree of influence of reiterations is statistically significant and amounts to $0.2 \%$.

The difference between the average for the repetition determine using Student's $t$ test is 0.9585 (less than $H_{0.95}=$
$=1.265977)$. Consequently, as the results of field experiment are similar to the results of computer experiment, it can be concluded that the use of derived equations for predicting emissions depending on the evenness is competent.

Suppose that evenness is taken as satisfactory $6 I R I$, and the actual evenness is $10 I R I$. Authors define the excess of $\mathrm{CO}_{2}$ emission $(P)$ at traffic $(N)$ equal to 10,000 vehicle/day.

$$
\begin{aligned}
& M_{\mathrm{CO}_{2}}^{I R I 6}=0.5297 \cdot 10^{2}+ \\
&+53.4463 \cdot 10+ \\
&+6.6314=594.064 \\
& \mathrm{t} /(\text { year } \cdot \mathrm{km}) \\
& M_{\mathrm{CO}_{2}}^{I R I 10}=0.4585 \cdot 10^{2}+ \\
&+62.8997 \cdot 10- \\
&-12.8252=660.5868 \\
& \mathrm{t} /(\text { year } \cdot \mathrm{km}) \\
& P=66.52 \mathrm{t} /(\text { year } \cdot \mathrm{km})
\end{aligned}
$$

If the cost parameter from the impact of greenhouse gas $\mathrm{CO}_{2}$, as in European methods (Bickel and Friedrich 2005), equals $3.33 \mathrm{USD} / \mathrm{t}$, the monetary value of the excess emissions will be $221.5 \mathrm{USD} /($ year $\cdot \mathrm{km})$. 
In this way, the excess of emissions of other gases can be identified and the total sum of additional damage can be determined.

\section{CONCLUSIONS}

1. The developed method of greenhouse (and other) emission inventory from automobile-road complex based on the results of road evenness monitoring permits not only to determine the total amount of emissions, but also to identify excess emissions relative to some acceptable level.

2. Value terms of excess emissions determine the sum of additional damage to the environment. This sum can be the basis for determining the amount of ban impositions on road service, which occur due to the fault excess emissions, which in turn serve as a tool for control of air pollution.

\section{REFERENCES}

BENNETT C.R. 1994: Vehicle Operating Cost, Speed, Environmental and Safety Modelling in HDM-4. International Workshop on HDM-4, November 1994, School of Civil Engineering, The University of Birmingham, UK.

BENNETT C.R. 1996: HDM-4 Emissions Model - Draft Specifications International Study of Highway Development and Management Tools. University of Birmingham, UK.

BERDIN V.H. et al. 2004: Greenhouse gases - a global environmental resource. Handbook. PA: WWF, Moscow, Russia.

BICKEL P., FRIEDRICH R. 2005: ExternE Externalities of Energy. Methodology $2005 \mathrm{Up}$ date. Office for Official Publications of the European Communities, Luxembourg.

GOLUB A.L., CHARLES D., KOLSTAD. 1995: Using Economic Incentives to Control Pollution in Russia. Market Problems Institute, Russian Academy of Sciences and Environ- mental Studies Program, University of California.

INOGAMOV F. 2007: Clean Development Mechanism for Sustainable Future. Ecological Bulletin 10: 6-12.

IPCC Guidelines for National Greenhouse Gas Inventories. Volume 2. Energy. 2006. IGES, Japan.

HAMMERSTROM U. 1995: Proposal for a Vehicle Exhaust Model in HDM-4 ISOHDM Supplementary Technical Relationships Study Draft Report. Swedish National Road Administration, Road and Traffic Management Division, Borlange Sweden: 120-145.

HOBAN C.J. 1987: Evaluating Traffic Capacity and Improvements to Road Geometry. World Bank Technical Paper 72: 340-356.

Methods of determining the emissions of harmful substances into the air from the motor flows moving along motorways. 2005. St. Petersburg Research Institute of Atmosphere, St. Petersburg.

ROCHAS M. 2006: Analysis of mechanisms for $\mathrm{CO}_{2}$ emission reduction in latvian energy installations. PhD thesis. Riga Technical University, Riga.

WATANATADA T., DHARESHWAR A.M. 1986: A Model for Predicting Free-Flow Speeds Based on Probabilistic Limiting Velocity Concepts: Theory and Estimation. Transportation Research Record 1091: 37-47.

WATANATADA T., DHARESHWAR A.M., REZENDE LIMA P.R.S. 1987: Vehicle Speeds and Operating Costs. HDM-III Series. The World Bank, John Hopkins University Press, USA.

Streszczenie: Monitorowanie stanu nawierzchni jako podstawa gospodarczej regulacji emisji gazów cieplarnianych. Kompleks drogowy, który obejmuje sieć dróg z ruchem kołowym, służby drogowe, zakłady napraw samochodów, przedsiębiorstwa produkcji paliw i materiałów do remontu dróg, jest ważnym źródłem zanieczyszczenia środowiska, a poziom zanieczyszczeń zależy od jakości nawierzchni drogowej. Przedstawione badania miały na celu znalezienie wzajemnej zależności między wielkością emisji do środowiska z całego kompleksu drogowego a stanem pokrycia drogi, stworzenie uproszczonego sposobu ustalania szkód gospodarczych związanych 
$\mathrm{z}$ zanieczyszczeniem środowiska $\mathrm{w}$ eksploatacji drogowej i rozwijanie podstawowego mechanizmu wpływu gospodarczego na usługi drogowe przy przekroczonym poziomie emisji. Zgodnie z wynikami eksperymentów komputerowych uzyskano matematyczne zależności emisji kompleksu drogowego od równości nawierzchni drogowej. Opracowana metoda inwentaryzacji szklarniowej (i innych) emisji pozwala na wyznaczanie całkowitej wielkości emisji i określenie nadmiernej emisji w stosunku do ustalonego, akceptowalnego poziomu. Definicja szkody gospodarczej zanieczyszczenia środowiska podczas eksploatacji drogi może być podstawą do ustalania wielkości sankcji pieniężnych nakładanych na służby drogowe.
Stowa kluczowe: gazy cieplarniane, szkody ekonomicznie, system pojazd-droga, równość pokryć drogowych, przekroczenia poziomu emisji

\section{MS. received in May 2014}

\section{Authors' address:}

Maria Radkevich

Tashkent Automobile and Road Construction Institute

Temur 20, Tashkent, Uzbekistan 100060

e-mail: maria7878@mail.ru 